\title{
Exposure to Dioxins and Furans at the Bormeh Kingtom Dumpsite in the Western Area of Sierra Leone
}

\author{
Abubakarr S. Mansaray¹, Abu-Bakarr Massaquoi Senior², Ibrahim Joe Samai, \\ Bashiru M. Koroma ${ }^{4}$ \\ ${ }^{1}$ Chemistry Department, Njala University, Njala, Sierra Leone \\ ${ }^{2}$ Former National Coordinator UNDP's GEF/SGP Program, Freetown, Sierra Leone \\ ${ }^{3}$ Action for Environmental Protection and Sustainable Development, Freetown, Sierra Leone \\ ${ }^{4}$ School of Community Health Sciences, Njala University, Bo, Sierra Leone \\ Email: absmansaray@gmail.com
}

Received 24 August 2015; accepted 22 September 2015; published 25 September 2015

Copyright (C) 2015 by authors and Scientific Research Publishing Inc.

This work is licensed under the Creative Commons Attribution International License (CC BY). http://creativecommons.org/licenses/by/4.0/

(c) (i) Open Access

\section{Abstract}

Humans and animals can be exposed to Dioxins and Furans through ingestion of fatty food, skin contact, and breathing contaminated air. Resulting health problems include skin disease, immune problems, and cancers. Managing the release of these chemicals is therefore important. The Stockholm Convention on Persistent Organic Pollutants requires parties to adopt measures that reduce sources of these chemicals. Sierra Leone developed its National Implementation Plan (NIP) in 2008, in compliance with this requirement. However, no known further steps have been taken, particularly at community level. In 2013, the UNDP's GEF/SGP funded a pilot project to manage the release of Dioxins and Furans from two dumpsites in Freetown, Sierra Leone. This work was sponsored with funds from that project. The work sought to delineate the exposure of communities within and around the Bormeh-Kingtom dumpsite (Kingtom, Kolleh town, Ascension town, Crab town, and Congo town) to the chemicals. The study considered sources of exposure, relative quantities generated per year, and the routes of exposure. This exposure study is a first step in managing the release from those sources. Enumerators deployed at the dumpsite every day, 7:00 AM to 6:00 PM, for three months, quantifying and recording source materials. The amount of source materials dumped per day informed calculation of Dioxin/Furan releases in grams toxicity equivalence per year. The results revealed a release of $128.914 \mathrm{~g}$ TEQ/year in air and residue. This implies that the communities are at high risk of inhalation and dermal exposure. Livestock, mainly pigs, are also exposed as they feed on the waste deposited in the dumpsite. Humans in turn feed on the livestock, a recipe for biomagnification. The project team has been working on developing Best Management Practices to suppress the release of the chemicals. 


\section{Keywords}

\section{Dioxins, Furans, Exposure, Biomagnification, Toxicity}

\section{Introduction}

People can be exposed to Polychlorinated dibenzo-p-dioxins (PCDD), commonly known as Dioxins, and polychlorinated dibenzofurans (PCDF), commonly known as Furans, by eating high-fat foods such as milk products, eggs, meat, and some types of fish. Burning of waste and the manufacture of chemical products containing these substances are potential sources of exposure as well [1]. In Sierra Leone, the largest source of dioxins and furans is the large-scale burning of municipal and medical waste [2]. Most of the waste burning takes place openly at dumpsites located in congested settlements within cities. In addition, the settlements have domestic animals that feed from these dumpsites. The community in turn depends on the animals as source of protein. Since dioxins and furans bioaccumulate in the food chain [3], this food consumption pattern is a public health concern in the population.

The health effects associated with human exposure to dioxins and furans include skin disorders such as chloracne, immune system impairments, endocrine disorders, reproductive problems, and developing nervous system and certain types of cancer [4]. An occupational health study has shown the carcinogenic nature of these chemicals, confirmed in 96.5\% effect in exposed workers in Hamburg, Germany [5].

The Stockholm convention on Persistent Organic Pollutants (POPs) requires signatories to take measures to reduce emissions with a view to eliminating the unintentional production of the POPs. The Government of Sierra Leone published its National Implementation Plan (NIP) in 2008 in fulfilling the commitment to signing the Stockholm Convention. However, no known action has followed the signing, ratification, and development of the NIP on POPs in Sierra Leone, albeit the continuity of activities that are known to release them in the environment.

There is limited access to documented POPs management at community level in the country. As a result, the United Nations Development Program (UNDP), in 2013, funded a pilot project through the Global Environment Facility's Small Grants Program GEF/SGP: managing the release of POPs from dumpsites in Sierra Leone. Part of the project objective was data gathering for source identification and quantification of POPs from the pilot sites. One of those sites was the Bormeh-Kingtom dumpsite. This paper presents results of the source identification and quantification at Kingtom.

The need for this work is obvious giving the lacking in data regarding the local sources and exposure to the chemicals. Nonetheless any effective and efficient management strategy will start with an understanding of the sources, quantities and routes of exposure at local level. A community level inventory would inform a more realistic Best Management Practice (BMP) and help clarify the national inventory as estimated in the NIP of 2008. Additionally, addressing the issue at pilot community level, and then scaling up to a national level will help eliminate gaps and resource burden. This work serves as a first step in establishing BMPs for mitigating the release of POPs at community level. The objective is to delineate the sources of Dioxins and Furans, relative amounts released per year, and the routes of exposure in communities within and around the Bormeh-Kingtom dumpsite: Kingtom, Kolleh town, Ascension town, Crab town, and Congo town. Results of this pilot study will hopefully inform replication at other potential hotspot areas the country.

The study was limited to field data gathering and calculations using models as developed in the United Nations Environment Program's (UNEP's) standardized toolkit. The model has been proven to have a good approximation of lab scale measurements. It was specially designed to help countries that lack resources in procuring expensive testing equipment.

\section{Materials and Methods}

\subsection{Description of Study Area}

Established in 1940 [6], the Bormeh-Kingtom dumpsite has since been receiving all categories of waste from central and western Freetown. The types of waste deposited at the dumpsite include the following: 
1) Solid waste: plastic (bottles, containers, shoes, ornaments, bags, etc.), dead animals, wood shavings, trees and branches, tins and cups, cans, bottles, clothing, leather, food leftovers, scrap metals, scrap tires, etc;

2) Liquid waste: raw sewage is the major liquid waste dumped at the side. Sewage from septic tanks and pit latrines in Freetown are disposed at the dumpsite;

3) Gaseous waste: volumes of smoke are emitted from the dumpsite all the time. The two main sources of smoke have been attributed to methane-air-heat ignition and deliberate fires;

4) Medical waste.

The dumpsite has been subjected to varying land cover over the years. Up until the late 1990s, the Kingtom dumpsite had a management scheme that approximated to a sanitary landfill. The site had a liquid waste treatment unit, separated from the solid waste unit. The liquid waste treatment system had a polder that received sewage from Freetown. The polder was designed to receive solar radiation and generate enough heat to kill bacteria. There was a sieve that separated the liquid from the sludge. The liquid drained into a lagoon that opened into the Sierra Leone River (gateway into the Atlantic Ocean) via a culvert on the west of the dumpsite. High tides brought water into the lagoon to dilute the liquid waste and then drifted away during low tide. The sludge was dried, bagged and sold to growers of flowers, carpet grass (Axonopus fissifolius), and similar plant types. Figure 1 shows a 2007 Google Earth picture of the Bormeh-Kingtom dumpsite with land cover including the polder, the lagoon, a culvert separating the lagoon and the river.

This land cover has changed a lot over the years. Emerging Koleh town community has back filled and replaced with homes the Polder, Lagoon, and most of the tidal zone of the Sierra Leone River (Figure 2).

The then Waste Management Unit in the Environmental Health Division of the Ministry of Health and Sanitation had a solid waste unit separated from the liquid waste system at the dumpsite. The team managed solid waste using heavy equipment to spread out the waste into layers and allow for additional waste disposal. Due to

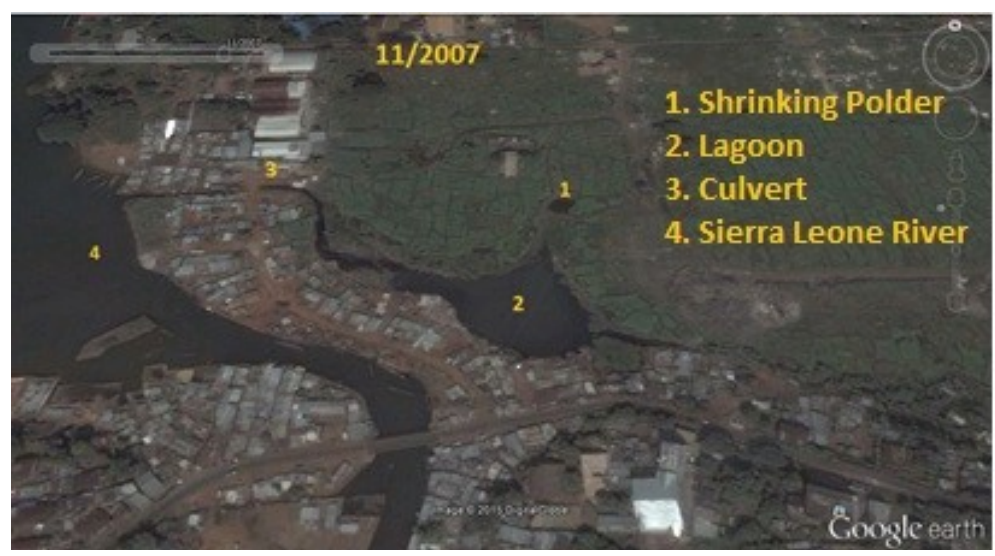

Figure 1. Google Earth image showing a 11/2007 picture of the dumpsite.

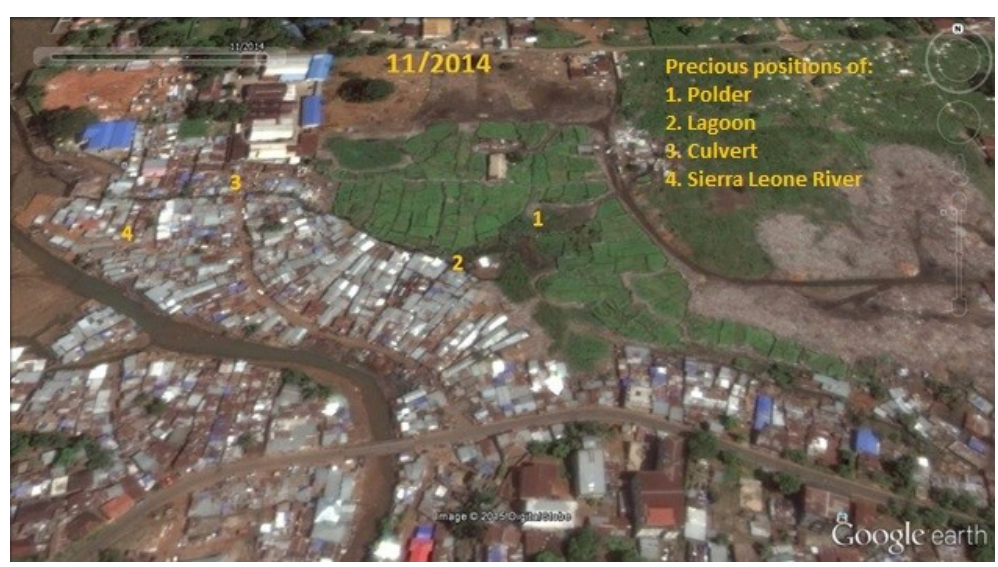

Figure 2. Google Earth image showing a 11/2014 picture of the dumpsite. 
growing human settlement, this scheme is no longer existent; the communities have expanded over the years, most of the dumpsite backfilled, and used for housing. Open uncontrolled burning replaced routine shredding and spreading of waste. In addition homes within the dumpsite block water ways and lead to formation of stagnated water bodies (Figure 3).

\subsection{Tools and Materials}

\subsubsection{The UNEP's Standardized Toolkit for Sources Applicable to Sierra Leone}

The Toolkit [7] focuses on activities under direct human control. In general, an air release of PCDD/PCDF is of concern at the local level. It is usually an issue of occupational exposure/worker hygiene, workplace design, and provision of suitable protective clothes-eventually including filter masks-to potentially exposed workers. Sierra Leone's National Implementation Plan for the Stockholm Convention on POPs identified and quantified the following Key Sources.

\section{1) Category 1: Waste incineration}

Combustion of medical waste

There is one so-called incinerator at the Makeni Government Hospital, in the Northern Province. The waste is inserted into two small openings of a bore hole that is paved, and then put on fire to burn. A lot of smoke is emitted as a result of incomplete combustion.

\section{2) Category 2: Power generation and heating}

Domestic heating and cooking

The quantities of domestic solid fuel and numbers/types of combustion appliances included wood/dry biomass, charcoal, petroleum products. Plastic materials are often used to kindle the burning of wood and charcoal. This is happening on a daily basis and so could contribute to increased flow of the PCDD/PCDF to the environment. Biomass is the major renewable energy used in Sierra Leone's households for cooking. The forest and agricultural by-products provide the main source of fuel wood used.

3) Category 3: Production of mineral products

The only significant source in this category in Sierra Leone is the cement production. The factory produces 456, 250 tonnes of cement per year.

\section{4) Category 4: Transport}

All vehicles use one of the two types of fuel: petrol (gasoline) or diesel. $85 \%$ of the vehicles imported are used cars, and $80 \%$ of them use gasoline.

\section{5) Category 5: Uncontrolled combustion processes}

Domestic waste combustion

Combustion of domestic waste is a major source of dioxins and furans, as this is one of the main means of getting rid of household waste. Part of the household waste comprises of plastics and other materials containing chlorine and metals that act as reactants in the formation of PCDD/PCDFs. Residues are likely to be left at the site, which may introduce the PCDD/PCDFs into the soil. There has been an increase in the volume and com-
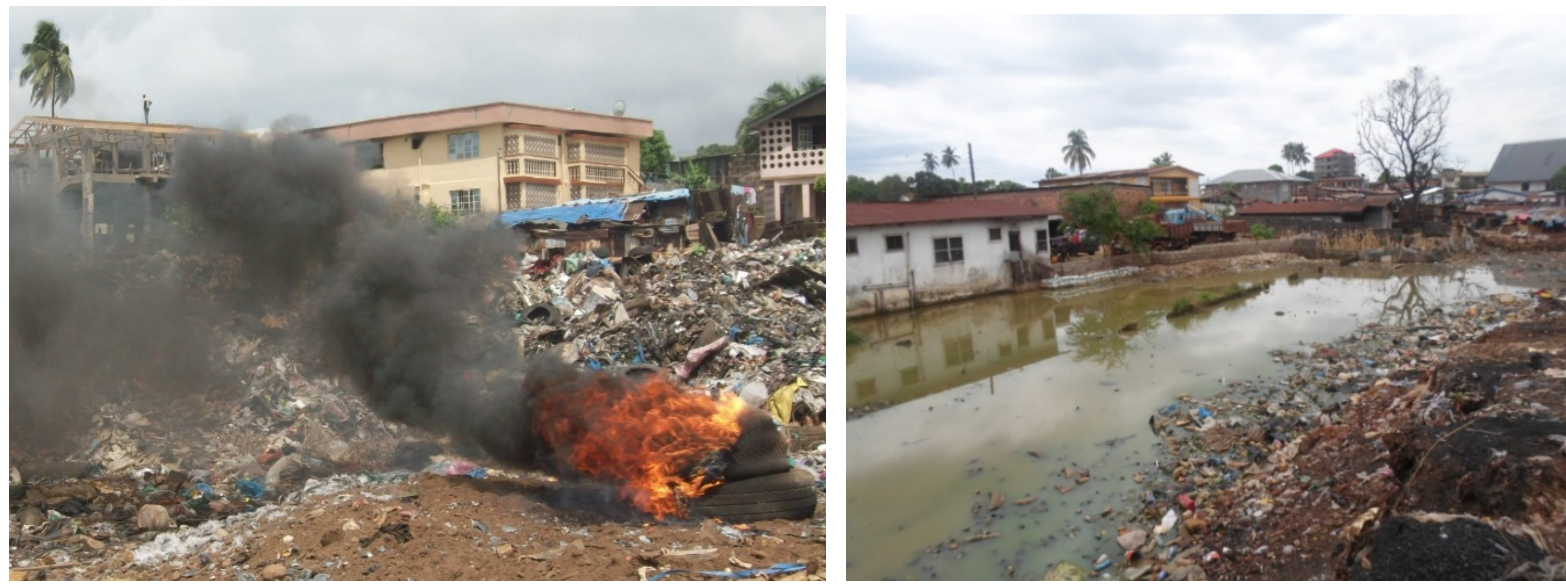

Figure 3. Current status of the Kingtom Bormeh Dumpsite. 
plexity of waste.

Dumpsite waste combustion

Waste combustion at dumpsites is likely to account for most of the dioxins and furans generated in the cities of Sierra Leone. The main dumpsites of the cities of Freetown, Bo, Kenema and Makeni use open burning as one of the main ways of reducing the volume of waste, to allow for continuous flow. No sorting mechanism was identified and so plastic and other chlorine/toxic metal containing substance are usually burned in combination with animal and plant waste. In addition to the main dumps, self-created dumps are seen all over the place in all the cities and towns. Residues are likely to be left at the site and subsequently end up in the soil and water bodies.

\section{6) Category 6: Disposal/landfill}

\section{Landfill leachate}

Waste dumps are a major source of PCDD/PCDF contamination to water. There are two main dumpsites in Freetown, Granville Brook and Bormeh King Tom, and many self-created dumpsites all of which are situated by water ways. This same situation applies to the cities of Bo in the south (two main dumpsites), Kenema in the east (one main dumpsite), and Makeni in northern Sierra Leone (one main dumpsite). Many activities that lead to leaching of chemicals, surface runoff, etc., happen on a daily basis; the dumpsites are normally situated in valleys that are flanked by water bodies.

Application of sewage sludge to the land is a major practice both in the houses and at dumpsites. All cesspit bowsers empty their contents at the Bormeh King Tom dumpsite directly on the land. This is similar in other cities. Most of the homes in the country empty their sewage sludge in dug holes at the backyard (pit latrines and few septic tanks).

All categories of waste are dumped at backyards and dumpsites. The ashes left from burning are mostly applied to gardens or are just abandoned.

\section{Open water dumping}

There are few industrial processes in the country but continuous discharge of wastewater into streams goes on. The industrial activities include brewing and beverage production, small scale gara tie-dying, soap making, etc. Wastewater discharge from homes may account for most of the UPOPs release to water (dish waters, soapy water, wash water, direct dumping of sewage sludge and other waste types).

\section{Waste oil disposal}

Oil spillage is very common in all operating power stations either in drainages or at the edge field of small streams and swampy areas. There is no evidence of proper handling facilities even at the power stations in Freetown.

\subsubsection{Materials}

\section{Weighing Material}

The site workers used a heavy duty dial scale to weigh source materials. A general multipurpose scale for bulk weighing, the instrument features a large, easy to read metal plate dial marked up to $50 \mathrm{~kg}$. There is a heavy duty cast iron on which the source materials are hanged.

\section{Data Gathering}

The enumerators used a spreadsheet to take log of vehicles depositing the waste materials at the dumpsite. They took records of vehicle types and their specifications, types of materials brought in, number of visits per day and weight of materials proven to be sources of Dioxins and Furans [8].

\subsubsection{Personal Interview}

Residents within and around the dumpsite suggested their perceptions of exposure to the chemicals in question. The responses were useful in source identification as well as discussing the results obtained in source quantification.

\subsection{Deployment}

The team visited the site regularly for a total of 3 months. During visits, the team interviewed locals and visitors on their perception of exposure to the chemicals. Additionally, hired personnel deployed at the dumpsite's main entrance every day, 7:00 AM to 6:00 PM. During this time period, the team collected data on the following as 
listed below:

- Types and specifications of vehicles delivering waste at the dumpsite;

- Types of waste deposited at each visit;

- Weight of materials as sources of Dioxins and Furans;

- Identification of routes of exposure to the chemicals.

\section{Results and Discussions}

\subsection{Source Identification}

The list below presents categories of potential sources studied in the inventory. Figure 4 presents pictures of activities with POPs releasing materials/activities under review.

1) Organic waste (wood shavings, dead animals, branches, scrap paper, sewage);

2) Medical waste;

3) Plastic materials (water sachets and bottles, scrap tires, wearing, etc.);

4) Electronic waste (scrap computers, broken thumb drives, broken cell phones, empty ink jets).

\subsection{Source Quantification}

Sources of POPs at this dumpsite are mainly plastic materials, and plants [8]. These materials were placed in bags and then weighed on scales (Figure 5) to determine the weight of trips brought in by waste transporters. These weights were used in computing the flow rate of waste materials and the release of POPs at the dumpsite (Table 1).

The annual releases for all vectors from a source or a source category are calculated as adapted from the UNEP’s Standardized Toolkit (2001). The PCDD/PCDF emission is expressed in grams TEQ per year.
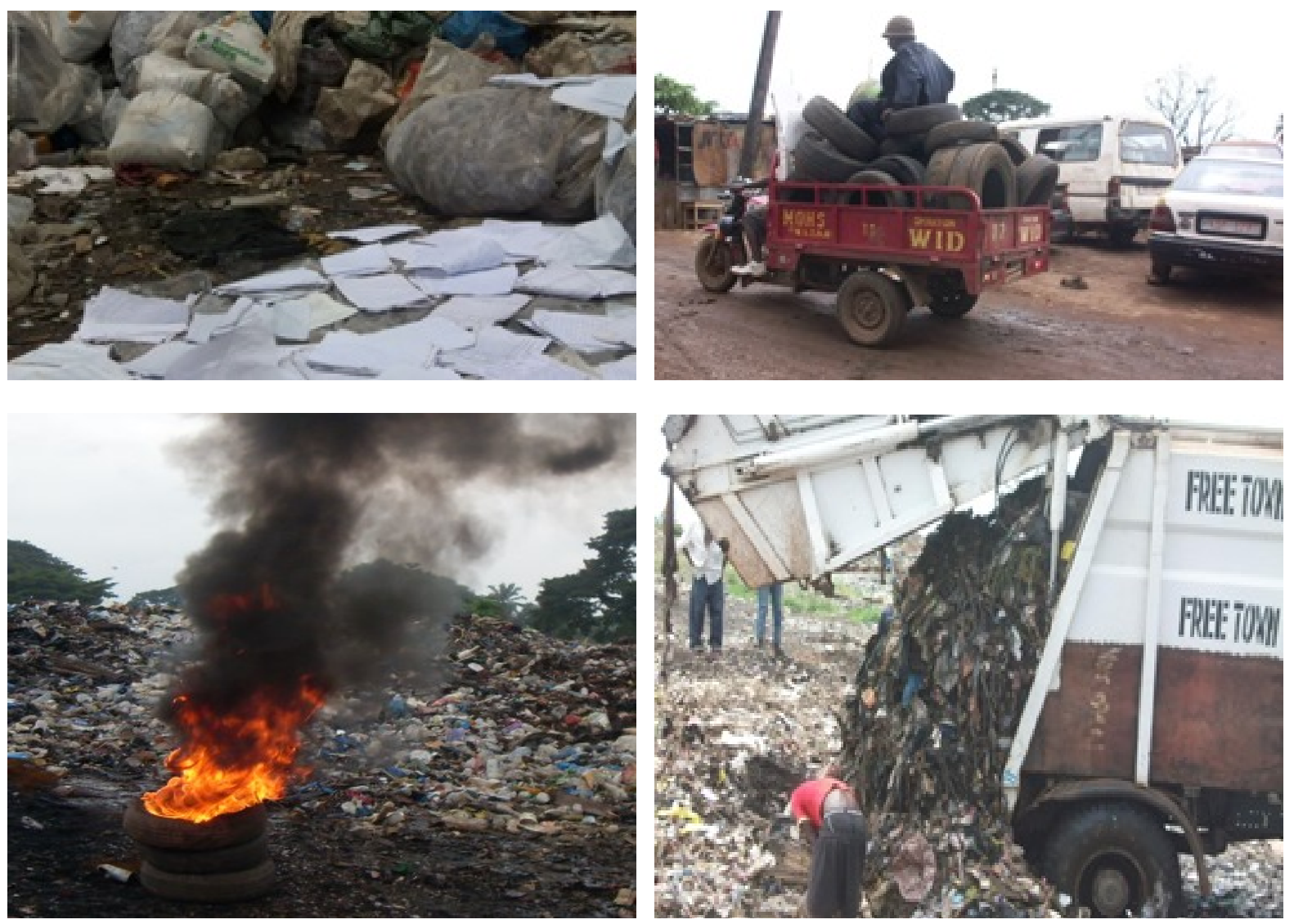

Figure 4. Potential sources of POPs from the Bormeh-Kingtom dumpsite in Freetown. 


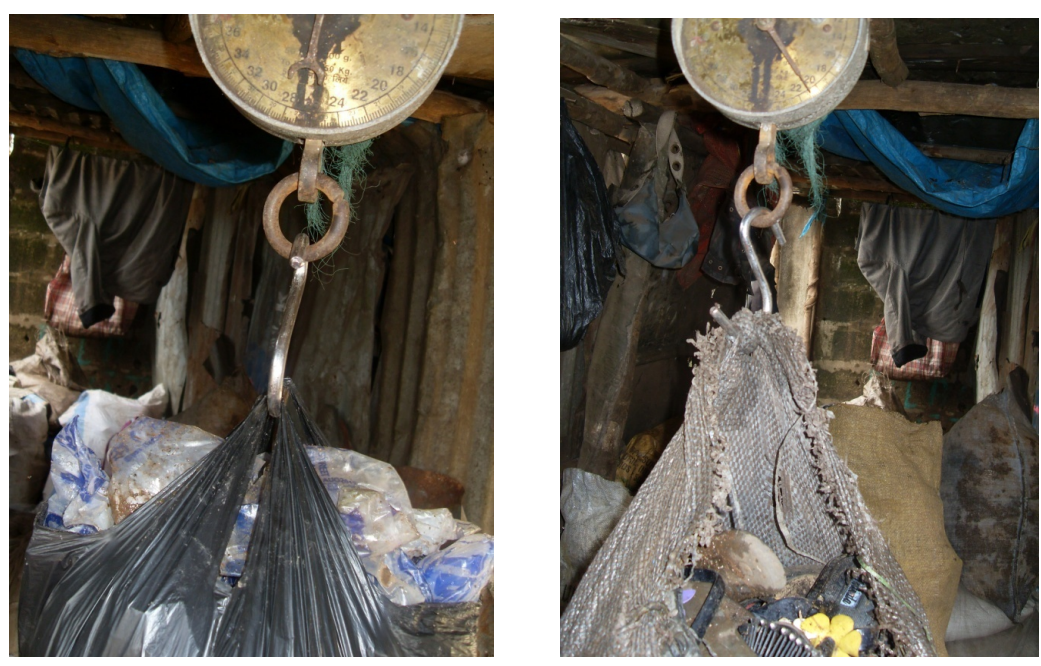

Figure 5. Weight determination of source materials.

Table 1. Flow rate of source materials.

\begin{tabular}{|c|c|c|c|c|c|c|c|}
\hline Vehicle detail & Dimension (m) & $\begin{array}{l}\text { Trips } \\
\text { per day }\end{array}$ & $\begin{array}{l}\text { Plastic sachet } \\
\text { (kg/day) }\end{array}$ & $\begin{array}{l}\text { Scrap papers/ } \\
\text { card (kg/day) }\end{array}$ & $\begin{array}{c}\text { Other plastic } \\
\text { materials (kg/day) }\end{array}$ & $\begin{array}{l}\text { Scrap tires } \\
\text { (kg/day) }\end{array}$ & $\begin{array}{c}\text { Wood } \\
\text { shavings } \\
\text { (kg/day) }\end{array}$ \\
\hline $\begin{array}{l}\text { Nissan: Freetown Waste } \\
\text { Management Company }\end{array}$ & $120 \times 65 \times 40$ & 4 & 10 & 8 & 6 & 1 & 10 \\
\hline $\begin{array}{l}\text { Ford: Freetown } \\
\text { Waste Mgt. Co. }\end{array}$ & $244 \times 106 \times 92$ & 3 & 12 & 15 & 8 & 3 & 12 \\
\hline $\begin{array}{l}\text { Compactor Farid: } \\
\text { Freetown Waste Mgt. Co. }\end{array}$ & $234 \times 106 \times 92$ & 12 & 13 & 10 & 26 & 15 & 12 \\
\hline Tricycle: Operation WID & $67 \times 47 \times 23$ & 15 & 7 & 6 & 3 & 2 & 5 \\
\hline Wheel Barrow & $58 \times 55 \times 13$ & 60 & 12 & 4 & 20 & 6 & 10 \\
\hline Individuals & & 30 & 5 & 3 & 12 & 0 & 4 \\
\hline Total & & 124 & 59 & 46 & 75 & 27 & 53 \\
\hline
\end{tabular}

Source strength (UPOPs emission per year) $=$ Emission Factor $\times$ Activity Rate

Activity Rate $=$ the amount of feed material processed or product produced in tonnes or litres per year. Each emission factor is the amount of PCDD/PCDF (in $\mu \mathrm{g}$ I-TEQ) that is released to any of the five vectors per unit of feed material processed or product produced (e.g., tonnes or litres). Default emission factors represent average PCDD/PCDF emissions for each class within each subcategory.

\subsubsection{Release from Biomass}

Biomass is the major renewable energy used for cooking in Sierra Leone's households. Forest and agricultural by-products provide the main source of fuel wood used (Koroma and Mansaray, 2008). Under the assumption that the heating value of $1 \mathrm{~kg}$ of wood is $14 \mathrm{MJ}$ and that almost all wood burned is collected in the forest and therefore virgin wood:

- 19.345 tons of waste wood is dumped per year (0.053 tons per day);

- 1 ton of wood has a heating value of $14 \mathrm{GJ}$ or $0.014 \mathrm{TJ}$;

- 19.345 tons of wood have a heating value of $0.014 \times 19.345=0.271 \mathrm{TJ}$;

- Virgin wood has emission factors of $100 \mu \mathrm{g}$ TEQ/TJ for air and $20 \mu \mathrm{g}$ TEQ/TJ for residue;

- Emission to air is $100 \times 0.271=27.1 \mu \mathrm{g}$ TEQ/year or $0.0271 \mathrm{~g}$ TEQ/year;

- In residues: $20 \times 0.271=5.42 \mu \mathrm{g}$ TEQ/year or $0.00542 \mathrm{~g}$ TEQ/year;

The combined UPOPs emission of POPs in the air and residues $=0.021+0.00542=0.026 \mathrm{~g}$ TEQ/year. 


\subsubsection{Emissions from Waste Burning}

The total source materials (apart from biomass) were estimated at $207 \mathrm{~kg} /$ day or 75.555 tons per year in total. The emission factor into air is $1,000 \mu \mathrm{g} T E Q / t$ for dumpsites.

$1000 \mu \mathrm{g} \mathrm{TEQ} / \mathrm{t} \times 75.555$ tonnes $=75.555 \mathrm{~g}$ TEQ/year, emission into air. As for emission into residue, the calculation yields $600 \mu \mathrm{g}$ TEQ/t $\times 75.555 \mathrm{t} /$ year $=45.333 \mathrm{~g} \mathrm{TEQ} /$ year.

The combined release per annum: $75.555+45.333=120.888 \mathrm{~g}$ TEQ/year.

Total UPOPS released from the BormehKingtom dumpsite is $120.888+0.026=128.914 \mathrm{~g} T E Q /$ year.

\subsection{Routes of Exposure}

The main routes of exposure are inhalation, skin contact and ingestion of food produced at or close to the dumpsite.

\subsubsection{Inhalation}

People living nearby (and within) the dumpsite do inhale the smoke emitted from open burning on a daily basis. There have been complaints of persistent and repeated illnesses. Five (5) residents informed the team of several visits to hospitals in attempt to cure the persistent illnesses. Many brands of malarial and typhoid treatments have not helped, they said. Studies have inculpated UPOPs of compromising the immune system, thereby making victims susceptible to persistent and repeated illnesses [9]. This smoke issue has come up in the news a number of times. In the November 2013 edition of the awareness Times Newspaper, there was the caption "In Sierra Leone, 'Garbage dump sites emit smoke dangerous to humans'” [10] (Figure 6).

\subsubsection{Dermal}

Inhalation is always accompanied by skin exposure to the smoke. Additionally, children playing in the dirt as well as adults scavenging for useful materials may be exposed via the release in residues (Figure 7).

\subsubsection{Ingestion of Food Grown in the Dumpsite}

Swine raring is one of the main economic activities at the dumpsite. The animals feed on waste materials deposited at the dumpsite. Figure 8 shows a typical swine raring and processing activity at the dumpsite. Studies have shown that POPs can accumulate in the fatty tissues of animals [11].

Vegetable gardening (Figure 9) is another major economic activity at the dumpsite. The vegetable is grown here for the advantage of organic manure. Release into residues may lead to uptake and hence bioaccumulation a

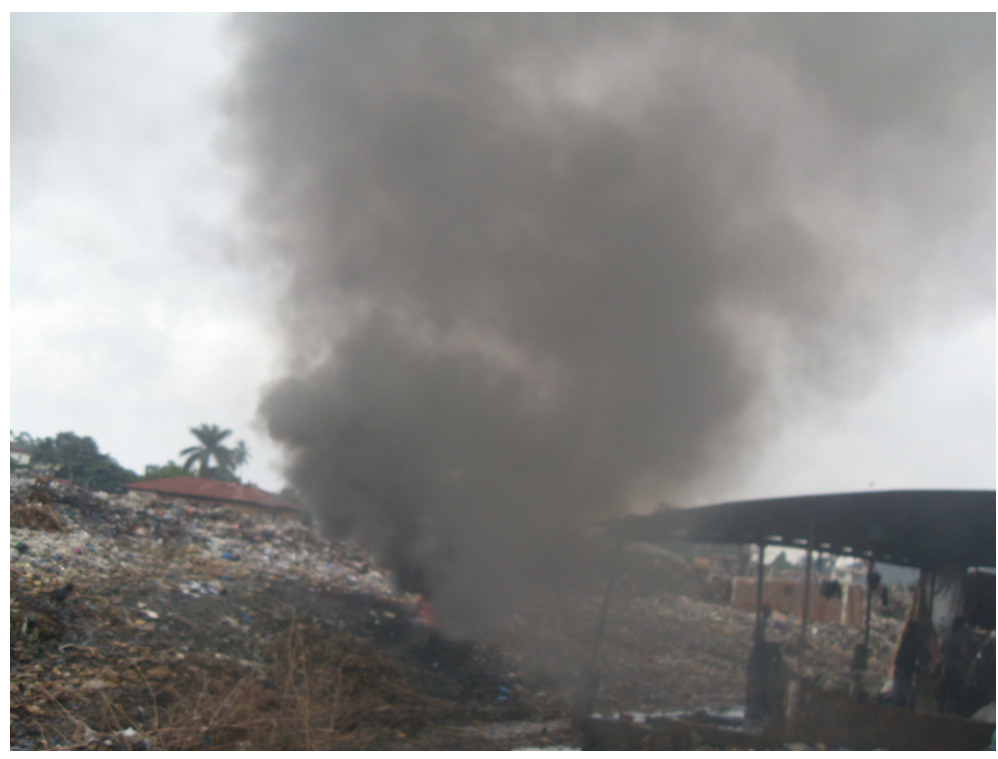

Figure 6. The neighborhood and scavengers are exposed to smoke all day long. 


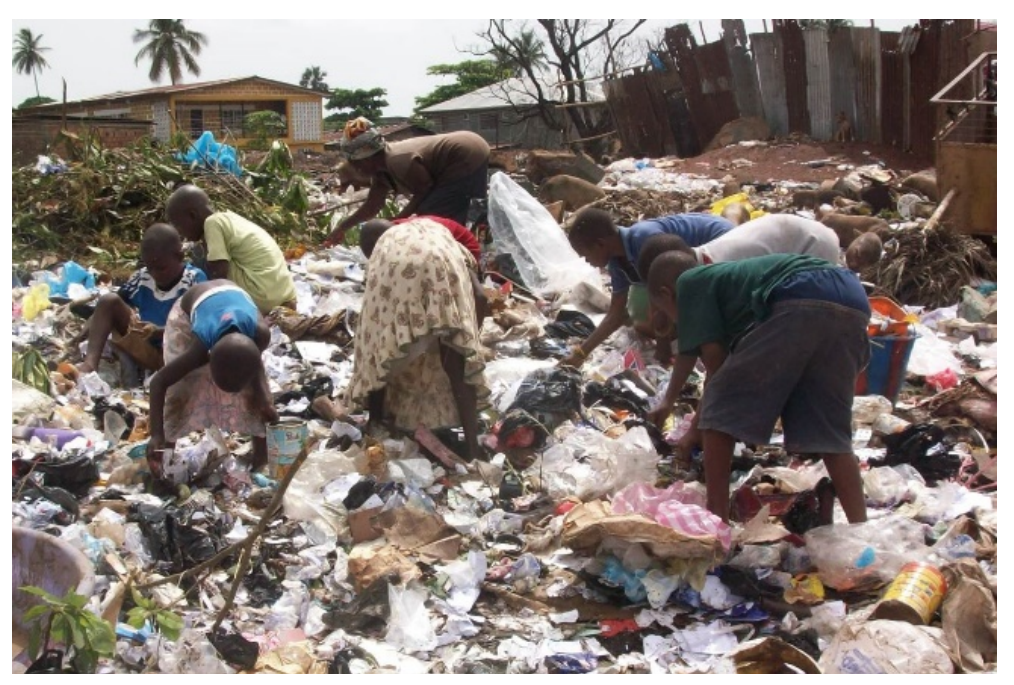

Figure 7. Scavengers may be exposed to POPs released in residues.
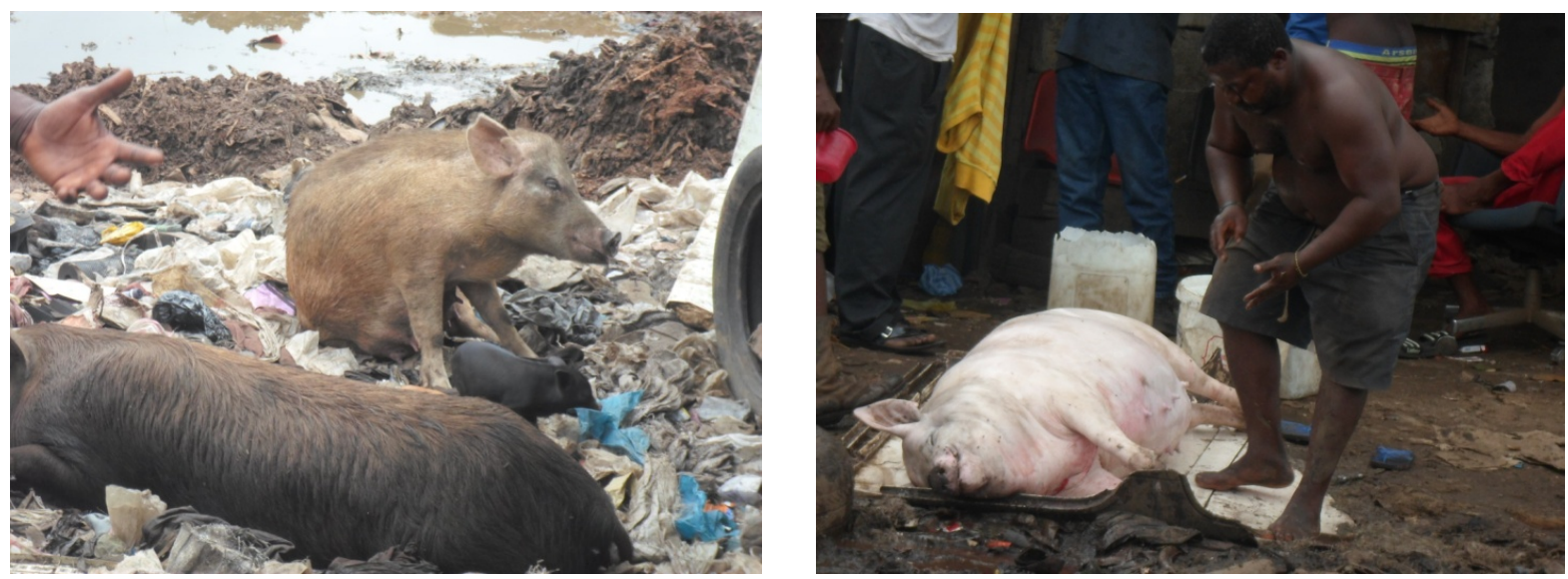

Figure 8. Swine industry at the dumpsite.

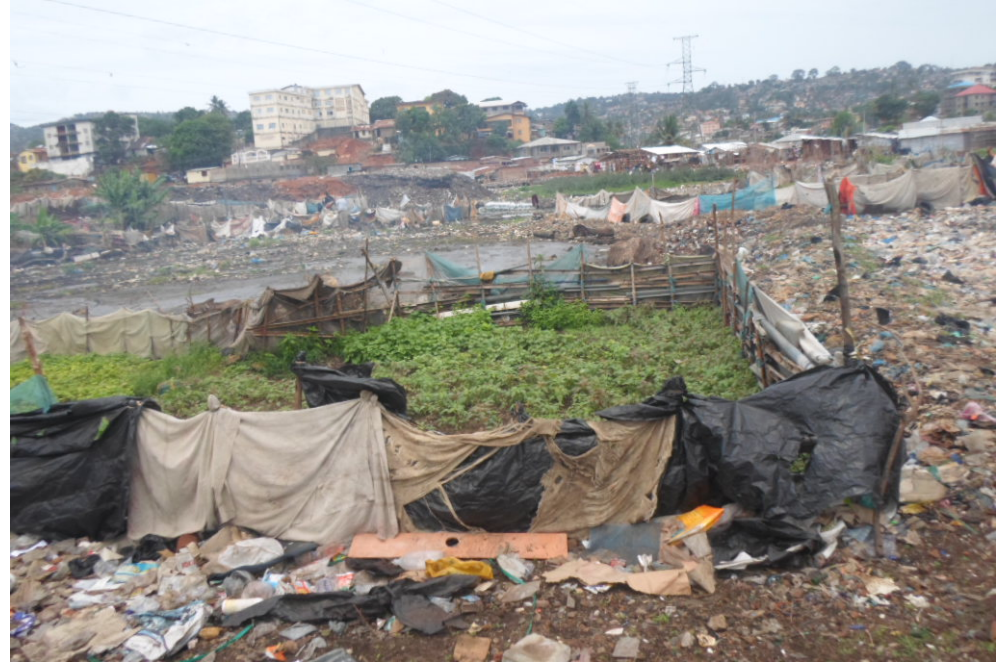

Figure 9. Vegetable gardening within the dumpsite. 
possibility. However vegetable uptake is less likely compared to accumulation in fatty tissues [12].

\section{Conclusions}

This work sought to delineate the exposure of people to dioxins and furans released from the Bormeh-Kingtom dumpsite. Activities included source identification, source quantification and identifying the routes of exposure.

The study asserted that a total of $128.914 \mathrm{~g}$ TEQ of dioxins and furans were released into the air and residues per year at the Bormeh-Kingtom dumpsite. This amount is limited to plastic materials and wood shavings; it does not include release from medical and other types of waste. This is a serious public health concern; dioxins and furans are among a host of chemicals that have been considered harmful to humans. The Stockholm Convention requires governments to adopt mitigation measures and improve the living standards of the world's populations.

Most of the POPs are released into smoke resulting from uncontrolled burning. The main routes of exposure are inhalation and dermal; ingestion of food produced at the dumpsite is also a major concern. The study findings confirmed the suspicion that human health problems could be attributed to POPs release from the dumpsite. A number of residents have complained of persistent and repeated illnesses. One problem of these POPs is that they compromise the immune system and render people susceptible to persistent health problems.

Domestication of the Stockholm convention to enhance a national policy and help mitigate POPs release would be the way forward. Sierra Leone is a signatory and has developed the National Implementation plan. Putting this plan into practice, led by agencies and the communities will be good practice. Thankfully, the Environmental Protection Agency Sierra Leone (EPA-SL) has started consulting with stakeholders on the matter [13]. Specifically, BMPs could include recycling and reuse of plastic materials, composting of organic waste, including sewage, relocation of cattle raring, and fire management strategies.

\section{Acknowledgements}

The team is thankful to the UNDP for providing GEF/SGP funds on Chemicals Management. We acknowledge the National Steering Committee (NSC) of the SGP for their technical support. Finally, we are thankful to the Kingtom community, especially the Kingtom Bormeh Environmental Protection Group for their support and contribution to data gathering.

\section{References}

[1] CDC (2009) Dioxins, Furans and Dioxin-Like Polychlorinated Biphenyls. Centres for Diseases Control and Prevention.

[2] Koroma, B.M. and Mansaray, A.S. (2008) Inventory of Unintentional Persistent Organic Pollutants (UPOPs). National Commission on Environment and Forestry, Freetown.

[3] WHO Media Centre (2014) Dioxins and Their Effects on Human Health. WHO.

[4] Schecter, A., Birnbaum, L., Ryanc, J.J. and Constable, J.D. (2006) Dioxins: An Overview. Environmental Research, 101, 419-428. http://dx.doi.org/10.1016/j.envres.2005.12.003

[5] Manuwald, U., Garrido, V.M., Berger, J., Manz, A. and Baur, X. (2012) Mortality Study of Chemical Workers Exposed to Dioxins: Follow-Up 23 Years after Chemical Plant Closure. Occupational and Environmental Medicine, 69, 636-642.

[6] Sankoh, S.K., Redwood-Sawyer, J.A.S., Karim, A.B. and Ndomahina, E.T. (2009) Report Prepared for the Waste Management in Sierra Leone. ACP-EU Cooperation Program in Higher Education, Freetown.

[7] UNEP Chemicals (2001) Standardized Toolkit for Identification and Quantification of Dioxin and Furan Releases. United Nations Environment Programme, Geneva.

[8] U.S. EPA (2011) Persistent Bioaccumulative and Toxic (PBT) Chemical Program: Dioxins and Furans. U.S. EPA, Washington DC.

[9] Gascon, M., Morales, E., Sunyer, J. and Vrijheid, M. (2013) Effects of Persistent Organic Pollutants on the Developing Respiratory and Immune Systems: A Systematic Review. Environment International, 52, 51-65. http://dx.doi.org/10.1016/j.envint.2012.11.005

[10] Awareness Times Newspaper (2013) In Sierra Leone, “Garbage Dump Sites Emit Smoke Dangerous to Humans” Says AESPD Program Manager. Local News, 22 November 2013.

[11] Ruzzin, J. (2012) Public Health Concern behind the Exposure to Persistent Organic Pollutants and the Risk of Meta- 
bolic Diseases. BMC Public Health, 12, 298. http://dx.doi.org/10.1186/1471-2458-12-298

[12] Wang, T.Y., Lu, Y.L., Zhang, H. and Shi, Y.J. (2005) Contamination of Persistent Organic Pollutants (POPs) and Relevant Management in China. Environment International, 6, 813-821. http://dx.doi.org/10.1016/j.envint.2005.05.043

[13] Awoko Newspaper (2015) Sierra Leone News: EPA Discourse National Implementation Plan on POP. Awoko, 6 September 2015. 